\title{
CHARACTERISATION OF HYDROXYAPATITE-TRICALCIUM PHOSPHATE BIOCERAMICS ISSUED FROM CA-DEFICIENT HYDROXYAPATITE POWDERS: INFLUENCE OF Ca/P RATIO
}

\author{
SYLVIE RAYNAUD, ERIC CHAMPION, DIDIER BERNACHE-ASSOLLANT \\ Science des Procédés Céramiques et de Traitements de Surface, UMR 6638, \\ 123, avenue Albert Thomas, 87060 Limoges, France.
}

\begin{abstract}
Calcium deficient hydroxyapatite with $\mathrm{Ca} / \mathrm{P}$ atomic ratio comprised between 1.5 and 1.667 were densified by hot pressing. Hot pressed powders were transformed into hydroxyapatite-tricalcium phosphate biphasic ceramics. After hot pressing at $1200^{\circ} \mathrm{C}$, fracture strength remained below $100 \mathrm{MPa}$, this was explained by the allotropic transformation $\beta \rightarrow \alpha$ of TCP above $1150^{\circ} \mathrm{C}$. Ceramics hot pressed at $1100^{\circ} \mathrm{C}$ had a fracture strength of $150 \mathrm{MPa}$ when the composition contained between $8 \mathrm{wt} \%$ and $12 \mathrm{wt} \%$ of $\beta$-TCP. For lower or higher $\beta$-TCP content the strength dropped. This proved the necessity of a precise determination of $\mathrm{Ca} / \mathrm{P}$ ratio. Quantitative $\mathrm{X}$-ray diffraction analysis allowed a better precision than wet chemical analysis with deviations below 0.005 on $\mathrm{Ca} / \mathrm{P}$ values.
\end{abstract}

\section{INTRODUCTION}

Several studies have been devoted to the synthesis of calcium deficient hydroxyapatite powders (Ca-dHAP) having a $\mathrm{Ca} / \mathrm{P}$ atomic ratio comprised between 1.5 and 1.667, with the aim of elaborating hydroxyapatite-tricalcium phosphate (HAP-TCP) bioceramics. ${ }^{1-4}$ Because reproducibility in hydroxyapatite synthesis and chemical characterisation have always been difficulties, relative deviations of $1 \%$ or $2 \%$ in the $\mathrm{Ca} / \mathrm{P}$ value of synthesised calcium phosphates are often considered acceptable. ${ }^{5,6}$ But, such deviations may result in different ceramic materials after sintering. ${ }^{7}$

From this basis, the aim of our work is to point out the importance of a precise determination of $\mathrm{Ca} / \mathrm{P}$ ratio of $\mathrm{Ca}-\mathrm{dHAP}$ powders on the understanding of mechanical characteristics of densified ceramics issued from these powders. 


\section{EXPERIMENTAL PROCEDURE}

Calcium phosphate powders of apatitic structure $\mathrm{Ca}_{10-\mathrm{x}}\left(\mathrm{PO}_{4}\right)_{6-\mathrm{x}}\left(\mathrm{HPO}_{4}\right)_{\mathrm{x}}(\mathrm{OH})_{2-\mathrm{x}}$ with $\mathrm{Ca} / \mathrm{P}$ atomic ratio ranging from 1.5 to 1.667 were synthesised from conventional precipitation method with $\mathrm{Ca}\left(\mathrm{NO}_{3}\right)_{2}$ and $\left(\mathrm{NH}_{4}\right)_{2} \mathrm{HPO}_{4}$ solutions. ${ }^{7}$ Because $\mathrm{Ca}-\mathrm{dHAP}$ powders are transformed into HAP/ $\beta$-TCP biphasic mixture when heated in the temperature range $800^{\circ} \mathrm{C}-1100^{\circ} \mathrm{C}$, the $\mathrm{Ca} / \mathrm{P}$ ratio of initial powders can be determined using quantitative X-ray diffraction analysis (QXRD) of biphasic calcined mixtures. ${ }^{8,9}$ Powders were calcined at $1000^{\circ} \mathrm{C}$ and prepared according to the AFNOR NF S 94-066 standard. XRD patterns were registered on a $\theta / \theta$ diffractometer (Siemens D5000) using $\mathrm{CuK} \alpha$ radiation with a step size of $0.02^{\circ}(2 \theta)$ and a step time of 19 seconds. For comparison classical wet methods were also performed (complexometry with EDTA for $\mathrm{Ca}$ and spectrophotometry for $\mathrm{P}$ ).

Powders were hot pressed (H.P.) at $1100^{\circ} \mathrm{C}$ or $1200^{\circ} \mathrm{C}$ during 30 min under a $20 \mathrm{MPa}$ compressive stress in an argon atmosphere. The relative density of hot pressed materials was determined by the Archimedean method in water. Sintered discs were cut into $20 \times 4 \times 3 \mathrm{~mm}^{3}$ bars that were polished with a $3 \mu \mathrm{m}$ diamond paste. Flexural strength was determined by 3 point bending of these bars with a $16 \mathrm{~mm}$ span and a crosshead speed of $0.2 \mathrm{~mm} \mathrm{~min}^{-1}$. Fracture toughness was determined by Vickers indentation technique using a $19.6 \mathrm{~N}$ applied load. $\mathrm{K}_{\mathrm{IC}}$ was calculated with Evans' equation. ${ }^{10}$

\section{RESULTS AND DISCUSSION}

$\mathrm{XRD}$ patterns of hot pressed ceramics (Figure 1) showed that at $1100^{\circ} \mathrm{C}$, calcium phosphates were biphasic compounds containing HAP and $\beta$-TCP. $\alpha$-TCP was present in the materials after heat treatment at $1200^{\circ} \mathrm{C}$. Thus, the allotropic transformation $\beta$-TCP $\Leftrightarrow \alpha$-TCP, which occurs above $1150^{\circ} \mathrm{C}$ during heating, was not reversible during cooling to room temperature.

Characteristics of hot pressed ceramics are given in table 1. Pure TCP exhibited a much lower densification ratio than pure HAP and its presence modified the sintering kinetics of biphasic materials. Ceramics containing less than $30 \mathrm{wt} \%$ of $\beta$-TCP hot 
pressed at $1100^{\circ} \mathrm{C}$ were nearly fully dense whereas residual porosity increased noticeably with increasing TCP content. After hot pressing at $1200^{\circ} \mathrm{C}$, results were similar to that found at $1100^{\circ} \mathrm{C}$ and confirmed the low sinterability of TCP.

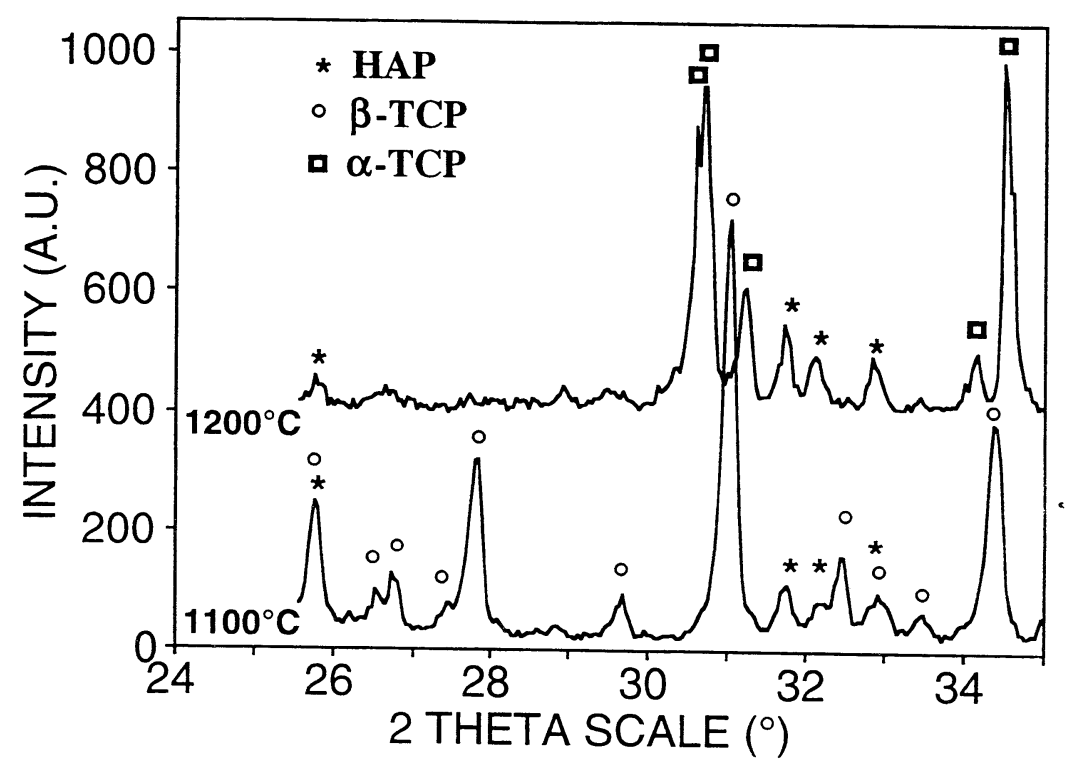

FIGURE 1. XRD patterns of calcium phosphate hot pressed at $1100^{\circ} \mathrm{C}$ and $1200^{\circ} \mathrm{C}$ (composition $77 \mathrm{wt} \%$ TCP and $23 \mathrm{wt} \% \mathrm{HAP}, \mathrm{Ca} / \mathrm{P}=1.536$ ).

TABLE 1. Composition, densification ratio and flexural strength of hot pressed HAP/TCP biphasic ceramics.

\begin{tabular}{cccccc}
\hline $\begin{array}{c}\text { Initial Ca/P } \\
\text { molar ratio }\end{array}$ & $\begin{array}{c}\text { after H.P. } \\
\left(\% \mathrm{~d}_{\mathrm{th}}\right)\end{array}$ & $\begin{array}{c}\text { Densification } \\
\left(100^{\circ} \mathrm{C}\right.\end{array}$ & $\begin{array}{l}\sigma_{1100^{\circ} \mathrm{C}} \\
(\mathrm{MPa})\end{array}$ & $\begin{array}{l}\text { Densification } \\
\left(\% \mathrm{~d}_{\mathrm{th}}\right)\end{array}$ & $\begin{array}{c}\sigma_{1200^{\circ} \mathrm{C}} \\
1200^{\circ} \mathrm{C}\end{array}$ \\
\hline 1.667 & 0 & 97.8 & $76 \pm 25$ & 98.9 & $98 \pm 20$ \\
1.663 & 2 & 99.8 & $122 \pm 20$ & 99.9 & $76 \pm 10$ \\
1.653 & 8 & 99.1 & $152 \pm 20$ & 98.0 & $98 \pm 15$ \\
1.646 & 12 & 98.2 & $149 \pm 30$ & 96.2 & $55 \pm 25$ \\
1.617 & 28 & 99.0 & $127 \pm 20$ & 98.8 & $84 \pm 40$ \\
1.536 & 77 & 85.4 & $90 \pm 10$ & 92.5 & $30 \pm 5$ \\
1.500 & 100 & 83.8 & $46 \pm 10$ & 86.0 & $18 \pm 4$ \\
\hline
\end{tabular}


Concerning the mechanical characteristics, the fracture toughness was almost constant whatever the composition might be with $\mathrm{K}_{1 \mathrm{C}}=1.0 \pm 0.2 \mathrm{MPa} \mathrm{m}^{1 / 2}$ after hot pressing at $1100^{\circ} \mathrm{C}$ and $\mathrm{K}_{1 \mathrm{C}}=0.6 \pm 0.1 \mathrm{MPa} \mathrm{m}^{1 / 2}$ at $1200^{\circ} \mathrm{C}$. Conversely, the flexural strength of biphasic ceramics depended strongly on the composition referred to the initial $\mathrm{Ca} / \mathrm{P}$ ratio. For dense materials hot pressed at $1100^{\circ} \mathrm{C}$ (containing less than $30 \mathrm{wt} \%$ of $\beta$-TCP), the fracture strength doubled from $75 \mathrm{MPa}$ up to $150 \mathrm{MPa}$ when the $\mathrm{Ca} / \mathrm{P}$ ratio decreased from 1.667 to 1.653 , i.e. from pure $\mathrm{HAP}$ to biphasic ceramics containing 8 wt\% of $\beta$-TCP. Then, the strength decreased for lower $\mathrm{Ca} / \mathrm{P}$ values. The low strength measured on ceramics containing high amounts of $\beta$-TCP (from 77 wt\%) could be explained by the low densification ratio of these materials. After hot pressing at $1200^{\circ} \mathrm{C}$, the fracture strength of ceramics remained always below $100 \mathrm{MPa}$. Moreover, an important dispersion in strength values was noted, showing a very poor reliability.

Finally, the high temperature treatment of $1200^{\circ} \mathrm{C}$ led to more brittle materials. The low mechanical characteristics of ceramics hot pressed at $1200^{\circ} \mathrm{C}$ could be explained by the transformation $\beta$-TCP $\Leftrightarrow \alpha$-TCP. The transformation is accompanied with an important variation of volume of about $7 \%$. This variation should induce the appearance of residual stresses within the materials that are detrimental to the mechanical reliability. Residual stresses may even provoke the creation of microcracks which could account for the variability in strength and the decrease in toughness from $1 \mathrm{MPa} \mathrm{m}{ }^{1 / 2}$ at $1100^{\circ} \mathrm{C}$ down to $0.6 \mathrm{MPa} \mathrm{m}^{1 / 2}$ at $1200^{\circ} \mathrm{C}$. Therefore, the $\beta$-TCP to $\alpha$-TCP transformation must be avoided to prevent a brittlening of materials. This may be achieved providing sintering is performed at a temperature that does not exceed $1150^{\circ} \mathrm{C}$. In this case, $\beta$-TCP may act as a mechanical reinforcement for HAP matrices with an important strengthening effect when present in low amount.

These results also show that a relative deviation as low as $1 \%$ in the experimental determination of $\mathrm{Ca} / \mathrm{P}$ may constitute a serious drawback in bioceramics characterisation. The accuracy in the determination of this parameter is crucial. QXRD analysis of biphasic calcium phosphates (HAP/ $\beta-\mathrm{TCP})$ calcined at $1000^{\circ} \mathrm{C}$ allowed us to establish that the ratio of two integrated intensities, each one corresponding to one of the two phases, was related with a good accuracy to phase proportions according to the following empirical equation : 


$$
\mathrm{R}=\frac{\text { I phase } 1}{\mathrm{I} \text { phase } 2}=\frac{\mathrm{A} \times \text { weight } \% \text { phase } 1}{\mathrm{~B}-\text { weight } \% \text { phase } 1}
$$

Diffraction peaks were chosen to minimise experimental errors and fitting discrepancies on empirical constants $\mathrm{A}$ and $\mathrm{B}$. The most appropriated peaks corresponded to the reticular plane (0 2210$)$ for $\beta$-TCP phase and to the plane $\left(\begin{array}{lll}2 & 1 & 0\end{array}\right)$ for HAP when this phase is in major proportion or to the plane $\left(\begin{array}{lll}2 & 1 & 1\end{array}\right)$ for HAP phase when HAP is in minor proportion in the biphasic mixture. Therefore, two ratios of integrated intensities were used to the quantification :

$$
\mathrm{R}_{1}=\frac{\mathrm{I}_{\mathrm{HAP}}\left(\begin{array}{lll}
2 & 1 & 1
\end{array}\right)}{\mathrm{I}_{\beta}-\mathrm{TCP}\left(\begin{array}{llll}
0 & 2 & 10
\end{array}\right)} ; \mathrm{R}_{2}=\frac{\mathrm{I}_{\beta-\mathrm{TCP}}\left(\begin{array}{lll}
0 & 2 & 10
\end{array}\right)}{\mathrm{I}_{\mathrm{HAP}}\left(\begin{array}{lll}
2 & 1 & 0
\end{array}\right)}
$$

Figure 2 gives the relative deviation on $\mathrm{Ca} / \mathrm{P}$ values calculated from $\mathrm{QXRD}$ analysis. The precision varied with the chemical composition. In the worst case (i.e. materials containing about $50 \mathrm{wt} \%$ of each phase), the method allowed to determinate $\mathrm{Ca} / \mathrm{P}$ values with experimental errors below $0.4 \%$ whereas that obtained with wet methods was $2.5 \%$. Nevertheless, complementary qualitative techniques such as infrared spectrometry appeared helpful to ensure the purity of initial Ca-dHAP powders before calcination for QXRD analysis.

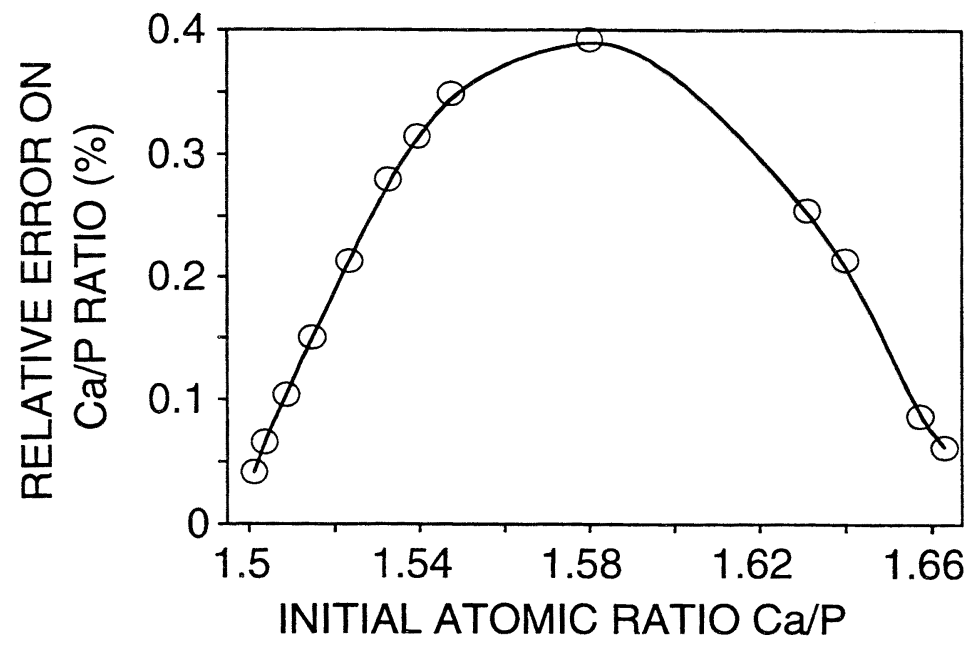

FIGURE 2. Relative error on $\mathrm{Ca} / \mathrm{P}$ atomic ratio determined from $\mathrm{QXRD}$ analysis. 


\section{CONCLUSION}

HAP/TCP bioceramics having very different properties can be obtained inside a very small domain of composition. Therefore, a great attention must be given to experimental errors on the measurement of $\mathrm{Ca} / \mathrm{P}$ ratio. QXRD analysis appears as a very accurate technique to determinate this parameter when $\mathrm{Ca} / \mathrm{P}$ is comprised between 1.5 and 1.667. Tricalcium phosphate can reinforce hydroxyapatite matrices but the characteristics of biphasic calcium phosphate ceramics depend on sintering conditions. Sintering must be performed at a temperature below $1150^{\circ} \mathrm{C}$ to prevent the detrimental effect of TCP phase transformation. To this end, hot pressing appeared helpful.

\section{REFERENCES}

1 A. Slosarczyk, E. Stobierska, Z. Paszkiewicz and M. Gawlicki, J. Am. Ceram. Soc., 79, 2539, (1996).

2 N. Kivrak and A. C. Tas, J. Am. Ceram. Soc., 81, 2245, (1998).

3 M. Vallet-Regi, L. M. Rodriguez-Lorenzo and A. J. Salinas, Solid State Ionics, 101$\underline{103}, 1279,(1997)$.

4 M. Toriyama, A. Ravaglioli, A. Krajewski, G. Celotti and A. Piancastelli, J. Eur. Ceram. Soc., 16, 429, (1996).

5 R. A. Young and D. W. Holcomb, Calcified Tissue Int., 34, 17, (1982).

6 J. Arends, J. Christoffersen, M. R. Christoffersen, H. Eckert, B. O. Fowler, J. C. Heughebaert, G. H. Nancollas, J. P. Yesinowski and S. J. Zawacki, J. Crystal Growth, $\underline{84}, 515,(1987)$.

7 S. Raynaud, E. Champion and D. Bernache-Assollant, in Bioceramics Vol.11, Edited by R. Z. LeGeros and J. P. LeGeros (World Scientific Publishing Co., New York, 1998), pp. 109-112.

8 N. Balmain, R. Legros and G. Bonel, Calcified Tissue Int., 34, S93, (1982).

9 K. Ishikawa, P. Ducheyne and S. Radin, J. Mat. Sci. Mater. Med., 4, 165, (1993).

10 A. G. Evans and E. A. Charles, J. Am. Ceram. Soc., 59, 371, (1976). 